\title{
The Educational Animation as the Instructional Material Gives Positive Effects Towards the Early Childhood Development
}

\author{
Ni Luh Bela Kristiani ${ }^{1 *}$, I Wayan Widiana ${ }^{1}$, I Gede Astawan ${ }^{1}$ \\ ${ }^{1}$ Department of Basic Education, Universitas Pendidikan Ganesha, Indonesia \\ ${ }^{*}$ Corresponding author. Email: bellakristiani3@gmail.com
}

\begin{abstract}
This study aims to determine the quality of the development of instructional materials aided by educational animated film media to increase motivation for early childhood learning. The development model used in this study is the ADDIE model. Model ADDIE consist of analyze, design, development, implementation and evaluation. from the five stages, two of them were not used because of limited time and situations which made it impossible to carry out implementation and evaluation activities. Three of the development stages are used as a reference in producing and validating the developed teaching instrument. The validation of the teaching material instrument was carried out by three experts namely material experts, instructional design experts, and education evaluation experts. Data was collected using a questionnaire method to test the validity of the material, lesson plans, and LKPD. The results of this study are obtained teaching material to develop early childhood learning motivation which is valid based on expert tests with the results of the CVR and CVI values of 1.00 .
\end{abstract}

Keywords: Teaching Materials, Educational Animated Film Media, Learning Motivation

\section{INTRODUCTION}

Education takes an important role in creating the next generation. Nowadays, the education not only becomes an obligation, but also becomes the people needs that assist them in developing themselves. According to [1], the education is defined as the people's needs that always follow the current technology and culture development. In early independence of Indonesia, the government tends to focus on primary, secondary, and high education, meanwhile in the present time, the government also focuses on developing the early childhood education as well. This attention is a commitment of the Indonesian government as a member of United Nations toward the result of Educational for All meeting which held at Dokar in 2000. Since that moment, the early childhood education becomes a central issue in education especially in Indonesia.

First education that must be taken by the children is early childhood education. [2] stated that early childhood education is a series of systematic and programmed efforts in developing the children since they are born until 6 years old by giving education stimulus to support their growth and development before taking the higher education. This age becomes an appropriate circumstance for the children to learn. Suryani in [3] added that early childhood education can be a base for the next human resources development.

Montessori stated that children come into the golden age since they are born until six years old where they begin to be sensitive toward any stimulus given [4]. During this age, the children have high curiosity toward their environment, even though the concentration rate is short. Therefore, the motivation is needed to maintain their activity to reach the goal optimally. The competency standard of early childhood education which is attached in early childhood education purposes is to support the development of any children's psychological and physical potencies such thing as religious, social emotion, cognitive, language, art, and physical motor. Those potencies are developed through various activities and used as teaching or learning materials in early childhood education. [5] defines that the instructional material is consisted of cognitive, psychomotor, and affective aspects that must be acquired by students in order to reach the competency standard. As added by Lestari in [6] the instructional material is defined as a set of materials that is systematically arranged in written of 
other form in creating a comfortable atmosphere during the learning process. [7] stated that instructional material is any materials including information, tools, or text that systematically arranged through displaying the whole competency that will be mastered by the children with learning implementation planning and review purposes.

Nasution in [8] argued that the goal of developing the instructional material is to give opportunities for the children to learn in their own pace. In addition, the instructional material development becomes a guidance for the teachers in directing their learning activities and becomes an assessment for evaluating the learning results [8]. Therefore, the teachers can use their time more in doing their functions as an advisor, a lecturer, a motivator, and a facilitator during the learning process [9]. Through well-prepared instructional material, the children will be able to learn a basic competency in wellorder and systematic ways [10].

One of challenges that face by the teachers is developing the instructional material as a tool that is used to reach the education goal. The teachers are required to be able to develop their instructional materials, but in current situation many teachers are less enthusiastic in doing their profession, especially in developing the instructional material. One of competencies that must be reached by the teachers in developing their job is to develop the instructional material. In line with Hamalik in [11], professional teachers must have well-integrated skills, a good mentality, and wide insight and knowledge. The instructional material development is essential to conduct in creating more effective, efficient, and accurate learning process as pointed in the learning competency. Miarso in [12] argued the use of instructional materials in the learning process, such as (1) it gives various stimulus to the brain in order to reach the optimal function, (2) it covers the children's weakness, (3) it gives the children an opportunity to conduct independent learning based on their own chance and speed.

Besides the use of appropriate instructional materials, the students' interest toward the instructional material and media must be given a serious attention. The success of instructional materials is affected by several factors such as teachers, students, media, and environment [13]. Besides those factors, the children's motivation in the learning process must be noticed because the children's motivation will increase the quality of the learning process. Arigiyati in [14] added that those who have big motivation will show their interest, attention, full concentration, high perseverance, and achievement oriented without having boringness and giving up. As mentioned by Asnawir in [15], the teachers can make use of the advantages of multimedia to facilitate the instruction process and to stimulate the children in learning. Gagne \& Briggs [16] stated that the teachers as a team in arranging the learning process must choose the appropriate method, design, and learning strategy such as using appropriate media. The attractive media and instructional materials will directly enhance the children's motivation to learn. Motivation is a change of self-energy which is indicated by feeling and reaction to reach a specific goal [17]. Without high motivation, the learning process will not be as effective as expected. It proves that the children's motivation must be in well maintenance in order to reach the expected goal. Lawson in [18] argued that the intensity of the children's effort to learn is based on their motivation level. Sardirman in [19] stated that the difference of the children's motivation level becomes an issue during the process of reaching the learning goal in school. Thus, the current research is expected to be a source in developing the educational animation as a media to develop the early childhood development.

\section{METHOD}

This study is development research (Research and Development). The ADDIE is used as the research model. It consisted of five stages, specifically: Analyze, Design, Development, Implementation, and Evaluation. Peterson in [20] defines that ADDIE model is a simple framework that useful to design the learning scenario where the setting can be implemented anywhere because of its general structure. The implementation of ADDIE in the study is in analyze stage. The stage is preliminary study which aim to gain information related to current issue and product that will be developed as a solution of that issue. During this stage, the educational animation as an instructional media of early childhood education is designed. The activities in this stage are consisted of material drafting, LKPD, and RPP. The drafting of the material, the LKPD, and the RPP on early childhood education level is conducted according to the design stage. The development is a continuation of the design stage. During this stage, the validity of the instructional material is tested by experts in a purpose to revise its weakness. The validity test is carried out by the learning design expert, the education evaluation expert, and the expert of learning materials on early childhood education. The checklist questionnaire is used as the validity test instrument. The questionnaire is a data collecting method in form of a questions set that is given to the respondent [21]. The data analysis technique used in the research is instrument validity instrument by using Content Validity Ratio (CVR) and Content Validity Index (CVI) formula as illustrated bellow.

$$
\begin{aligned}
& C V I=(\Sigma C V R) / k \\
& C V I=\text { Content Validity Index } \\
& C V R=\text { Content Validity Ratio } \\
& \mathrm{k} \quad=\text { Number of items }
\end{aligned}
$$


$C V R=\left(\frac{2 n e}{n}\right)-1$

$C V R=$ Content Validity Ratio

$2 n e=$ Validator who give agreement toward the instructional material (It is considered as agree when the score of every aspect is in the range of $3,00-4,00$, if $<3,00$ the instructional material is invalid)

$\mathrm{n} \quad=$ The number of previous validator

\section{FINDING AND DISCUSSION}

The result of early product development of the study is educational animation media to increase the early childhood motivation. The instructional material development is consisted of (1) the early childhood education material including 16 questions in the assessment instrument, (2) LKPD with 14 questions in the assessment instrument, and (3) RPP with 12 questions in the assessment instrument. The validity test that is conducted by the experts in order to find out the theoretical appropriateness of the instrument. The validity result is analyzed using Content Validity Ratio (CVR) [22] Furthermore, it is continued using Content Validity Index (CVI) formula to calculate the CVR mean score. Based on the instructional material validity including PAUD, LKPD, and RPP, it is found that each of them obtains score 1 for CVR and CVI. Additionally, the validity test result will be presented in Table 1 , Table 2, and Table 3, meanwhile the experts' comments and suggestions will be illustrated in Table 4, Table 5, and Table 6.

Table 1. The Validity Result of The Early Childhood Education Material

\begin{tabular}{|c|c|c|c|c|c|c|c|}
\hline \multirow{2}{*}{ No } & \multirow{2}{*}{$\begin{array}{l}\text { Scoring } \\
\text { Aspects }\end{array}$} & \multirow{2}{*}{ Indicators } & \multicolumn{3}{|c|}{ Experts } & \multirow{2}{*}{ CVR } & \multirow{2}{*}{ Inf. } \\
\hline & & & 1 & 2 & 3 & & \\
\hline \multirow[t]{7}{*}{1} & \multirow{7}{*}{$\begin{array}{l}\text { Content } \\
\text { Appropriateness }\end{array}$} & 1. The suitability of the basic and core competency & $\mathrm{B}$ & $\mathrm{B}$ & A & 1.00 & Valid \\
\hline & & 2. The difficulty level of the questions & $\mathrm{B}$ & $\mathrm{B}$ & $\mathrm{B}$ & 1.00 & Valid \\
\hline & & 3. The clarity of the material description & A & A & $\mathrm{B}$ & 1.00 & Valid \\
\hline & & $\begin{array}{l}\text { 4. The authenticity of the instructional material } \\
\text { substance }\end{array}$ & A & A & $\mathrm{B}$ & 1.00 & Valid \\
\hline & & 5. Fill up the curriculum standard & A & $\mathrm{B}$ & $\mathrm{B}$ & 1.00 & Valid \\
\hline & & $\begin{array}{l}\text { 6. The suitability of the material and students' } \\
\text { condition }\end{array}$ & A & $\mathrm{B}$ & $\mathrm{B}$ & 1.00 & Valid \\
\hline & & 7. Clear system of the presentation & A & $\mathrm{B}$ & $\mathrm{B}$ & 1.00 & Valid \\
\hline \multirow[t]{4}{*}{2.} & \multirow{4}{*}{$\begin{array}{l}\text { Language } \\
\text { Appropriateness }\end{array}$} & 1. The readability & A & A & A & 1.00 & Valid \\
\hline & & 2. The clarity of the information & A & $\mathrm{B}$ & $\mathrm{B}$ & 1.00 & Valid \\
\hline & & 3. The appropriateness toward $E Y D$ & A & $\mathrm{B}$ & $\mathrm{B}$ & 1.00 & Valid \\
\hline & & 4. Communicative & $\mathrm{B}$ & A & $\mathrm{B}$ & 1.00 & Valid \\
\hline \multirow[t]{5}{*}{3} & \multirow[t]{5}{*}{ Presentation } & 1. The clarity of the purposed indicators & $\mathrm{B}$ & $\mathrm{B}$ & $\mathrm{B}$ & 1.00 & Valid \\
\hline & & 2. The provision of motivation and attraction & A & A & $\mathrm{B}$ & 1.00 & Valid \\
\hline & & 3. Interaction (stimulus and responds) & $\mathrm{B}$ & $\mathrm{B}$ & $\mathrm{B}$ & 1.00 & Valid \\
\hline & & 4. The variety of questions format & A & A & $\mathrm{B}$ & 1.00 & Valid \\
\hline & & $\begin{array}{l}\text { 5. The presented pictures are related and supported } \\
\text { the clarity of the material }\end{array}$ & $\mathrm{B}$ & A & $\mathrm{B}$ & 1.00 & Valid \\
\hline \multicolumn{6}{|c|}{ CVI } & 1,00 & Valid \\
\hline
\end{tabular}

Table 2. The Validity Results of the $L K P D$

\begin{tabular}{|c|c|c|c|c|c|c|c|}
\hline \multirow{2}{*}{ No } & \multirow{2}{*}{ Scoring Aspects } & \multirow{2}{*}{ Indicators } & \multicolumn{3}{|c|}{ Experts } & \multirow{2}{*}{ CVR } & \multirow{2}{*}{ Inf. } \\
\hline & & & 1 & 2 & 3 & & \\
\hline \multirow[t]{4}{*}{1} & \multirow{4}{*}{$\begin{array}{l}\text { Language } \\
\text { Appropriateness }\end{array}$} & 1. The presentation system of the $L K P D$ & A & A & $\mathrm{B}$ & 1,00 & Valid \\
\hline & & 2. The clarity of work guidance & $\mathrm{B}$ & & $\mathrm{B}$ & 1,00 & Valid \\
\hline & & 3. As an essential materials or tasks & A & $\mathrm{B}$ & $\mathrm{B}$ & 1,00 & Valid \\
\hline & & 4. $\quad$ Clear activities & $\mathrm{B}$ & A & $\mathrm{B}$ & 1,00 & Valid \\
\hline \multirow[t]{4}{*}{2} & \multirow{4}{*}{$\begin{array}{l}\text { Language } \\
\text { Appropriateness }\end{array}$} & 1. The suitability toward $E Y D$ & $A$ & A & $\mathrm{B}$ & 1,00 & Valid \\
\hline & & $\begin{array}{l}\text { 2. The language is adjusted with the development } \\
\text { level of the students }\end{array}$ & A & $\mathrm{B}$ & $\mathrm{B}$ & 1,00 & Valid \\
\hline & & 3. $\quad$ Communicative & $\mathrm{B}$ & A & $\mathrm{B}$ & 1,00 & Valid \\
\hline & & 4. The clarity of the answers space & A & A & $\mathrm{B}$ & 1,00 & Valid \\
\hline \multirow[t]{6}{*}{3} & \multirow[t]{6}{*}{ Presentation } & 1. The clarity of the goal (the expected indicators) & $\mathrm{B}$ & $\mathrm{B}$ & $\mathrm{B}$ & 1,000 & Valid \\
\hline & & $\begin{array}{l}\text { 2. The presentation has an easy instruction to use } \\
\text { the book }\end{array}$ & $\mathrm{B}$ & A & $\mathrm{B}$ & 1,00 & Valid \\
\hline & & 3. The presentation order & $\mathrm{B}$ & A & A & 1,00 & Valid \\
\hline & & 4. The provision of motivation and attraction & A & A & A & 1,00 & Valid \\
\hline & & 5. Interaction (stimulus and responds) & $\mathrm{B}$ & A & $\mathrm{B}$ & 1,00 & Valid \\
\hline & & $\begin{array}{l}\text { The presented pictures are related and supported } \\
\text { the clarity of the material }\end{array}$ & A & A & B & 1,00 & Valid \\
\hline & \multicolumn{5}{|c|}{ (1) } & 1,00 & Valid \\
\hline
\end{tabular}


Table 3. The Validity Results of the $R P P$

\begin{tabular}{|c|c|c|c|c|c|c|c|}
\hline \multirow{2}{*}{ No } & \multirow{2}{*}{ Scoring Aspects } & \multirow{2}{*}{ Indicators } & \multicolumn{3}{|c|}{ Experts } & \multirow{2}{*}{ CVR } & \multirow{2}{*}{ Inf. } \\
\hline & & & 1 & 2 & 3 & & \\
\hline \multirow[t]{3}{*}{1} & \multirow{3}{*}{$\begin{array}{l}\text { Formulation of the } \\
\text { Learning Goals }\end{array}$} & 1. The clarity of the basic competency & A & A & B & 1,00 & Valid \\
\hline & & $\begin{array}{l}\text { 2. The suitability of the indicators and learning } \\
\text { purposes }\end{array}$ & $\mathrm{B}$ & A & $\mathrm{B}$ & 1,00 & Valid \\
\hline & & $\begin{array}{l}\text { 3. The suitability of the indicators and students' } \\
\text { development level }\end{array}$ & $\mathrm{B}$ & $\mathrm{B}$ & $\mathrm{B}$ & 1,00 & Valid \\
\hline \multirow[t]{4}{*}{2} & \multirow{4}{*}{$\begin{array}{l}\text { Content } \\
\text { Appropriateness }\end{array}$} & 1. The formulation system of $R P P$ & $A$ & A & $\mathrm{B}$ & 1,00 & Valid \\
\hline & & $\begin{array}{l}\text { 2. The instructional materials organization related } \\
\text { toward the indicators }\end{array}$ & A & A & $\mathrm{B}$ & 1,00 & Valid \\
\hline & & 3. The clarity of the learning scenario & A & $\mathrm{B}$ & $\mathrm{B}$ & 1,00 & Valid \\
\hline & & 4. The choice of learning sources, media, and tools & A & A & $\mathrm{B}$ & 1,00 & Valid \\
\hline \multirow[t]{3}{*}{3} & \multirow{3}{*}{$\begin{array}{l}\text { Language } \\
\text { Appropriateness }\end{array}$} & 1. The suitability toward $E Y D$ & A & $\mathrm{B}$ & B & 1,00 & Valid \\
\hline & & 2. Communicative & A & $A$ & $\mathrm{~B}$ & 1,00 & Valid \\
\hline & & 3. Simple structure of the sentences & A & A & $\mathrm{B}$ & 1,00 & Valid \\
\hline \multirow[t]{2}{*}{4} & \multirow[t]{2}{*}{ Time } & 1. The suitability in timing & A & $\mathrm{B}$ & $\mathrm{B}$ & 1,00 & Valid \\
\hline & & 2. The timing detail & A & B & B & 1,00 & Valid \\
\hline \multicolumn{6}{|l|}{ CVI } & 1,00 & Valid \\
\hline
\end{tabular}

In term of learning design, the first expert suggests that it is better to attach the guide firstly before the activities. Furthermore, in art development aspect, there are mistyping on the guidance, etc. The third expert suggests that in first stage, it should be the making of the instructional material before completing it with the questions. In addition, the presentation of the LKPD is good enough. For the RPP, it suggested to make the apperception and its learning scenario using the animation media to deliver the materials in purpose to give a clear view on how the animation media is used.

The LKPD is developed using worksheet that stimulate the development aspects. The product will be illustrated as the following pictures.
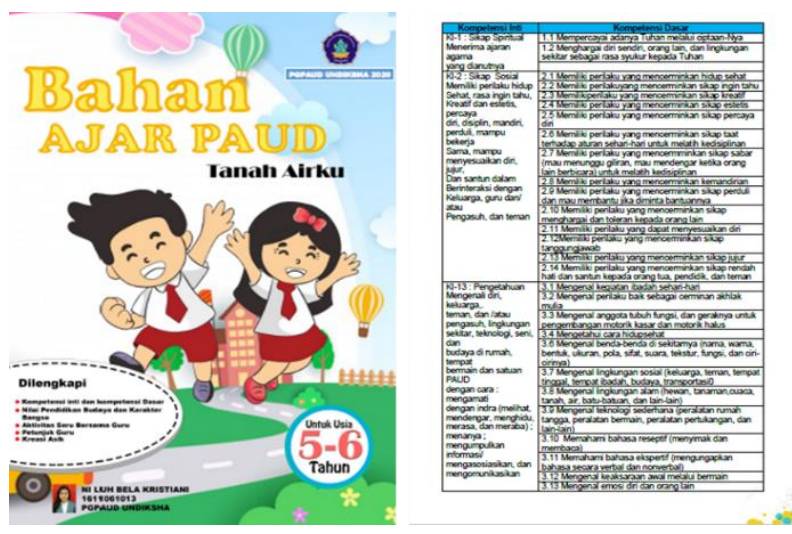

Figure 1. The cover and $R P P H$
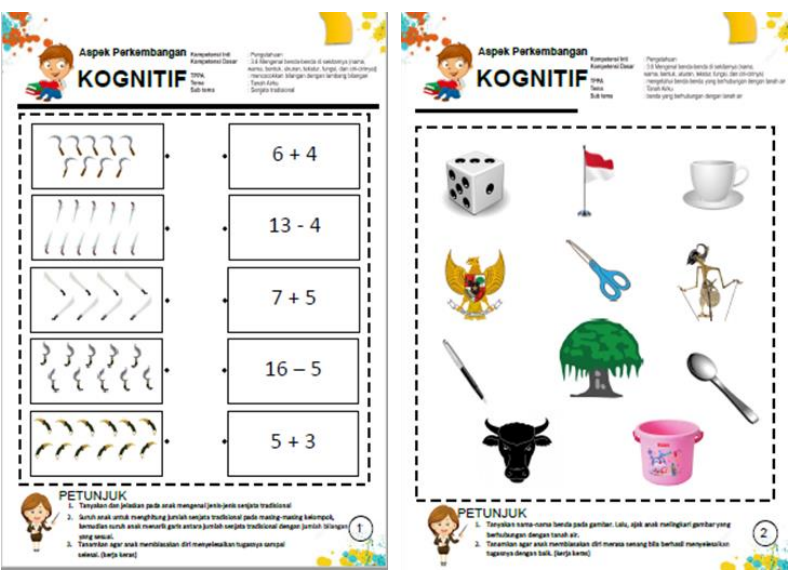

Figure 2. The worksheet
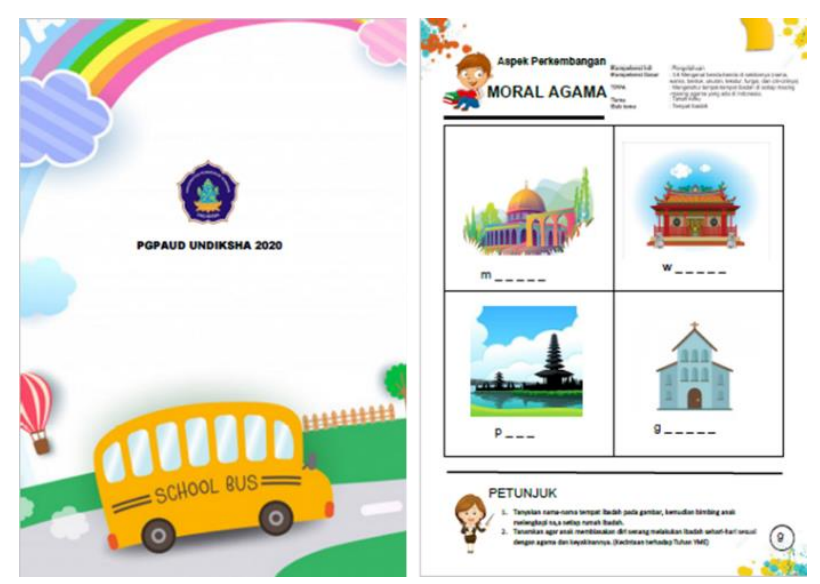

Figure 3. The worksheet

The result of the study is supported by Haryani which stated that there is a significant difference on the learning effectiveness using multimedia instructional materials and using conventional method. Another study by Sari added that the result of the study fulfils the attraction criteria, specifically $88 \%$ appropriateness percentage of 
the expert's judges, $84.4 \%$ percentage from the media expert, $97.5 \%$ percentage from instructional practitioner, and $98 \%$ percentage of the tryout result. The students learning achievement score of post-test control class is 67.66, meanwhile the score of the experimental class is 82.33. In manual t-test with mean of 0.05 , there is a result of t-hitung > t-tabel, that is 5,095 > 2,048 which means that Ho is rejected an $\mathrm{Ha}$ is not rejected. Therefore, there is a significant difference toward the students' learning achievement by using thematic instructional material based on pictures story.

Based on the result of the study, it can be concluded that the development of educational animation as an instructional media can be used by the teachers in teaching in order to increase the students' motivation. The result is supported by the theory of Rahayu and Partono in [10] which argued that the well-prepared instructional materials will be able to guide the students in learning a specific competency in well-order and systematic way. The instructional materials which is delivered using animation will be more attracted and motivated the students to learn. Educational animation is media that create imaginative moves as the result of picture shoots to show moves changes. In addition, this media delivers the learning messages in audio visual form and equipped by several element of moves. The media will always be attractive and well-accepted by the viewers especially the children [23]. There are several limitations in this study, specifically the instructional materials are only scooped in LKDP, early childhood education material, and RPP, the result of the instructional material development in the current research is not tested to the students, and the materials only tested by three experts, namely learning design expert, early childhood material expert, and instructional design expert.

\section{CONCLUSION AND SUGGESTION}

Based on finding and discussion, it can be concluded that the instructional material development specifically the early childhood education material with 16 question in assessment instrument gain score 1 in both the CVR and CVI. Furthermore, the instructional material development of LKPD that include 14 questions obtain score 1 for both CVR and CVI. Lastly, the development of instructional material in form of RPP including 12 questions gain score 1 for both CVR and CVI. Thus, it can be strongly concluded that the instructional material is already validity tested and it can be used as an instructional material in increasing the motivation of the early childhood in learning. The suggestions of the research can be formulated as follows: (1) the early childhood education teachers are suggested to use instructional material as the facility in increasing the early childhood motivation especially in B group, that is the ages of 5-6 years old, (2) the future researchers can use the current research as a source for issues in the learning process and look for other similar studies as references and consideration in conducting an akin development.

\section{REFERENCES}

[1] M. Yamin, Desain pembelajaran berbasis tingkat satuan pendidikan, Jakarta: Gaung Prasada Press, 2007.

[2] P. G. R. Cahyani, et. al, Pengaruh metode outbound terhadap kemampuan berpikir kretif kelompok B gugus I kecamatan sawan, Jurnal Pendidikan Anak Usia Dini 8(1) (2020) 35-44. Access at: https://ejournal.undiksha.ac.id/index.php/JJPAUD/ article/view/23419/15118

[3] H. Qudsyi, Optimalisasi pendidikan anak usia dini melalui pembelajaran yang berbasis perkembangan otak 18(2) (2010) 91-111. Access at: https://jurnal.ugm.ac.id/buletinpsikologi/article/vie w/11540/8606.

[4] T. Ariyanti, Pentingnya pendidikan anak usia dini bagi tumbuh kembang anak 8(1) (2016) 50-58. Access at: https://endahpujilestari1110029.wordpress.com/arti kel-paud-2/aud/artikel-pentingnya-pendidikananak-usia-dini-bagi-tumbuh-kembang-anak/

[5] Ministry of Education, Panduan pengembangan bahan ajar. Direktorat Pembinaan Sekolah Menengah Atas Direktorat Jendral Manajemen Pendidikan Dasar dan Menegah Departemen Pendidikan Nasional, 2006. Access at: http://staffnew.uny.ac.id/upload/131666733/penelit ian/15-pemanfaatanti.pdf

[6] S. Susilowati, Pengembangan bahan ajar terintegrasi nilai islam untuk meningkatkan hasil belajar IPA, Jurnal Pendidikan IPA 3(1) (2017) 2477-4820. Access at: https://journal.uny.ac.id/index.php/jipi/article/view/ $13677 / 0$

[7] A. Prastawo, Panduan Kreatif Membuat Bahan Ajar Inovatif, Yogyakarta: Diva Press, 2010.

[8] A. R. Putri, Pengembangan materi bahasa inggris untuk anak usia dini di paud pelangi guyangan, vol. 4(1) 2017. Access at: https://docplayer.info/67120905-Pengembanganmateri-bahasa-inggris-untuk-dini-di-paud-pelangiguyangan.html

[9] I. Falahudin, Pemanfaatan media pembelajaran, 1(4) (2014) 104-117. Access at: https://www.google.com/search?q=jurnal+Pemanfa atan+Media+Pembelajaran\&oq=jurnal+Pemanfaata $\mathrm{n}+$ Media+Pembelajaran\&aqs $=$ chrome..69i57j69i59 j016.7883j0j7\&sourceid=chrome\&ie $=U T F-8$ 
[10] S. W. Rahmawati, et. al., Pengembangan bahan ajar berbasis computer assisted intruction (CAI) pada pokok bahasa gerak harmonis sederhana di SMA. Jurnal Pembelajaran Fisika 6(3) (2017) 248-255. Access at: https://jurnal.unej.ac.id/index.php/JPF/article/view/ 5320

[11] S. Sukaesih, N. E. Kartijono, Pengembangan buku ajar microteaching biologi berbasis kompetensi dan karakter konservasi, Jurnal Pendidikan IPA 3(1) (2014) 79-85. Access at: https://journal.unnes.ac.id/nju/index.php/jpii/article /view/2904

[12] Sunismi, M. Nu'man, Pengembangan bahan pembelajaran geometri dan pengukuran model penemuan terbimbing berbantuan komputer untuk memperkuat konsepsi siswa, Jurnal Cakrawala Pendidikan, vol. 2, 2012. Access at: https://journal.uny.ac.id/index.php/cp/article/view/ 1557

[13] H . Umrotul, N. Lukman, Media pembelajaran film animasi sebagai media pembelajaran konsep fotosintesis 1(1) (2015) 91-106. Access at: http://jurnal.untirta.ac.id/index.php/JPPI/article/vie $\mathrm{w} / 283$

[14] R. Puspitorini, et. al., Penggunaan media komik dalam pembelajaran ipa untuk meningkatkan motivasi dan hasil belajar kognitif dan afektif, vol. 3, 2014. Access at: https://media.neliti.com/media/publications/86053none-5664b5b4.pdf

[15] K. Dewi, Pentingnya media pembelajaran untuk anak usia dini, 2016. Access at: http://jurnal.radenfatah.ac.id/index.php/raudhatulat hfal/article/view/1489

[16] M. Widiasanti, Y. Ayriza, Pengembangan media video animasi untuk meningkatkan motivasi belajar dan karakter tanggung jawab siswa kelas V, vol 1 2018. Access at: https://journal.uny.ac.id/index.php/jpka/article/vie w/21489

[17] I. R Lubis, J. Ikhisan, Pengembangan media pembelajaran berbasis android untuk meningkatkan motivasi belajar dan prestasi kognitif peserta didik SMA, vol. 1(2), 2015. Access at: https://journal.uny.ac.id/index.php/jipi/article/view/ 7504

[18] C. N. Aulina, Penerapan metode whole brain teaching dalam meningkatkan motivasi belajar anak usia dini. Jurnal Obsesi, vol. 2(1), 2018. Access at: https://www.academia.edu/37398778/Penerapan
Metode_Whole_Brain_Teaching_dalam_Meningka tkan_Motivasi_Belajar_Anak_Usia_Dini

[19] D. T. Santosa, T. Us, Faktor-faktor penyebab rendahnya motivasi belajar dan solusi penanganan pada siswa kelas XI jurusan teknik sepeda motor, vo. 13(2), 2016. Access at: http://journal.student.uny.ac.id/ojs/index.php/otom otif-s1/article/view/2896/2504

[20] I. M. Y. Premana, N. Suharsono, I. M. Tegeh, Pengembangan Multimedia Pembelajaran Berbasis Masalah Pada Mata Pelajaran Produksi Gambar 2D Untuk Bidang Keahlian Multimedia di Sekolah Menengah Kejuruan. Jurnal Teknologi Pembelajaran Indonesia, vol. 3(1), 2013.

[21] Sugiyono, Metode Penelitian Administrasi, Bandung: Alfabeta, 2014.

[22] C. H. Lawshe, A quantitative approach to content validity, Personnel psychology 28(4) (1975) 563575

[23] Y. W. Astuti, A. Mustadi, Pengaruh penggunaan media film animasi terhadap keterampilan menulis karangan narasi siswa kelas V SD. (Universitas Negeri Yogyakarta), Jurnal Prima Edukasia 2(2) (2014) 250-262. 